\title{
Biophilia as the Main Design Question in Architectural Design Studio Teaching
}

\author{
Mimari Tasarım Stüdyosu Eğitiminde Ana Tasarım Sorusu Olarak Biyofili
}

\author{
Kutlu SEVINÇ KAYIHAN, Sedef ÖZÇELIK GÜNEY, Faruk Can ÜNAL
}

\section{ABSTRACT}

The reflection of biophilia, a concept coming from the disciplines of psychology and philosophy, in architecture emphasizes the connection between a building and nature as the main input of architectural design. Various dimensions and design criteria have been defined under the main heading of biophilic architecture, with the objective of eliminating the gap between the natural and the built environment in today's modern cities. This study explored the approach of third year architecture students to biophilia embedded in the design studio program, rather than pursuing a formal, focused approach. The students' sensitivity to a building being a tool to connect nature and humans in urban settings and design reactions were assessed in the context of the major parameters mentioned in the literature.

Keywords: Architecture education; biophilia; biophilic design; design studio teaching.

ÖZ

Psikoloji ve felsefe disiplinlerinden gelen bir kavram olan "biyofili" nin mimarlıktaki yansıması, mimari tasarımın ana girdisi olarak bina ile doğa arasındaki ilişki üzerine odaklanmaktadır. Günümüz modern kentlerinde doğal çevre -yapma çevre arasındaki kopukluğun ortadan kaldırılması amacıyla "biyofilik mimarlık" ana başlığı altında çeşitli boyutlar ve tasarım ölçütleri tanımlanmıştır. Bu çalışmada, doğaya duyarlı bir tasarım ortamı yaratılması amacıyla, örneklenen mimarlık lisans programındaki tasarım stüdyosunda bu boyutlara dikkat çekilmektedir. Bununla birlikte tasarım stüdyosu öğrencilerinin odak noktası, binaların biçimsel odaklı bir yaklaşım ile tasarlanmasından ziyade, doğayı ve insanı kentsel ortamda bütünleştirmek için bir araç olarak tasarlanmasıdır. Bu çalışma, üçüncü yıl mimarlık öğrencilerinin tasarım stüdyosu programına dahil edilen biyofili kavramına yaklaşımını araştırmayı amaçlamaktadır. Bu bağlamda öğrencilerin doğa-bina ilişkisine olan duyarlılıkları, tasarım reaksiyonları ve sorunu ele alma biçimleri incelenmiştir. Öğrencilerin biyofili problemine yönelik eğilimleri, literatürde belirtilen başlıca parametrelere göre değerlendirilmiştir.

Anahtar sözcükler: Mimarlık eğitimi; biyofili; biyofilik tasarım; tasarım stüdyosu eğitimi.

Department of Architecture, Gebze Technical University, Architecture Faculty, Kocaeli, Turkey.

Article arrival date: April 05, 2017 - Accepted for publication: November 26, 2017

Correspondence: Kutlu SEVINÇ KAYIHAN. e-mail: sevinc@gtu.edu.tr

○ 2018 Yıldız Teknik Üniversitesi Mimarlık Fakültesi - ๑ 2018 Yıldız Technical University, Faculty of Architecture 


\section{Introduction}

The concept of biophilia is formed by the combination of the words "bio" and "philia". "Bio" stands for the word "live", or "being alive" and, "philias" refers to "the attraction and positive emotions people feel for certain living spaces, actions, and beings in the natural environment" This notion is just the opposite of phobia, meaning deep fears that people feel about objects in the natural world. Social psychologist Erich Fromm used the term in 1964 for the first time. He explains that, biophilia is the psychological obsession of being attracted by things that are alive and vital. It was used to describe the psychological orientation of "attraction to everything that is alive." ${ }^{1}$

The term is popularized by academician and entomologist E. O. Wilson which is defined as an "innate tendency to focus on life and lifelike processes", ${ }^{2}$ an "innate emotional affiliation of human beings to other living organisms" ${ }^{3}$ or, an "inborn affinity human beings have for other forms of life, an affiliation evoked, according to the circumstances, by pleasure, or a sense of security, or awe, or even fascination blended with revulsion" ${ }^{4}$ In his book, "Biophilia", Wilson ${ }^{5}$ suggests that the deep familiarity of humans to nature and their biology originate from biological production. Wilson ${ }^{6}$ argues that the value of human nature or the acceptance of nature comes to a great extent from birth. "If Wilson speaks about an innate tendency, he means by that the structure of our brains at least partially at the time of birth contains certain basic mental facilities that develop with contact with the external environment in a somewhat predictable fashion. ${ }^{7}$

Heerwagen and Hase stresses the hypothesis by Gordon Orians who has studied on habitat selection and its relevance to human environments. His hypothesis claims that humans are psychologically adapted to certain key landscape features that characterizes our ancestral habitat; the African savannah. The preferences of humans in the built environments shape accordingly. Due to the humans' long history as hunting and gathering bands on the African savannah, our psyche searches the traces of such environments in which the brain evolved. That is why common environmental anxieties such as heights, enclosed spaces, darkness, being in the open without protective cover and being alone in a strange place exist. ${ }^{8}$

Current tendencies in design neglects other inputs such as the psychological necessities or the preferences of human beings regarding built environments. In our era the building design considers certain criteria such as form and function ${ }^{9}$ or considers "the house as a machine to live in"10 When we talk about sustainable design traditionally, we

\footnotetext{
1 Fromm, 1964. 2 Wilson, 1984. $\quad{ }^{3}$ Wilson, 1993. 4 Wilson, 1994.

Wilson, $1984 . \quad 6$ Wilson, 1993.

8 Heerwagen and Hase, 2001. $\quad 9$ Ivar, 2006. $\quad{ }^{10}$ Le Corbusier, 1952.
}

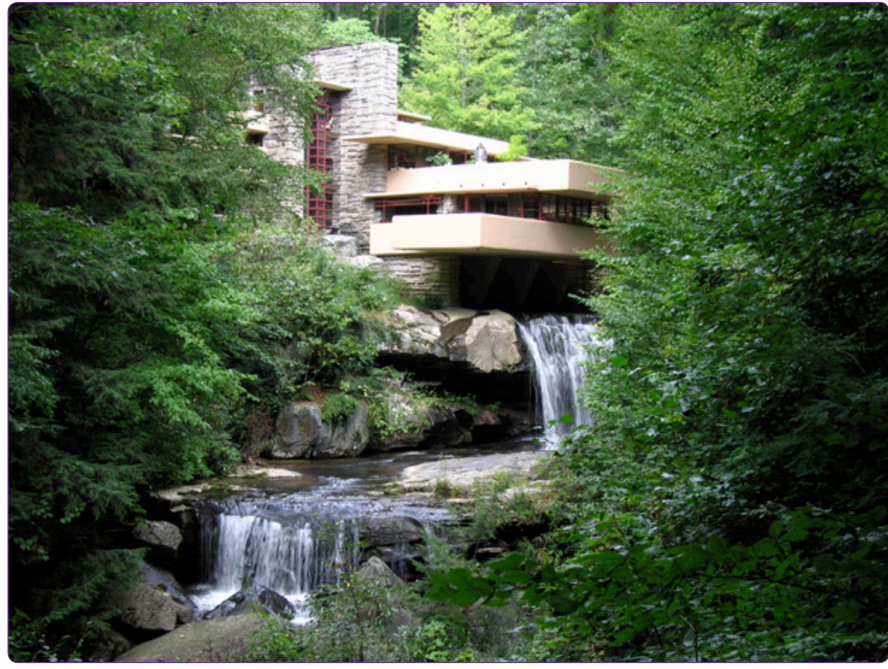

Figure 1. Frank Lloyd Wright's most famous house, Fallingwater. ${ }^{17}$

mean the various resources used in a building. So how we use water, gas and electricity, how much carbon produced over the structure life is a related approach. It is rather a question of experience quality offered by the building. "The challenge" of biophilic design is to stress the deficiencies of the contemporary building and the landscape. ${ }^{11}$ Kellert has developed the biophilia notion further and adapted the context to the built environment; in other words this idea has become one of the main elements in architectural design. Thus, biophilia proposes a thorough framework in order to satisfy the experience of nature in the built environment. ${ }^{12}$

Studies display that people who work in the environments with biophilic components are more effective, illnesses heal faster and students learn easier. ${ }^{13}$ The places with strong connection with the natural environment have positive effects on user psychology (e.g. increase of concentration, stimulant, soothing effect and etc.). Biophilic design patterns support stress reduction, cognitive performance, emotion-mood enhancement and the human body. Moreover in both outdoor and indoor empirical studies; there is evidence that visual contact with the natural elements catalyses healing. ${ }^{14}$ The decision to increase natural lighting and ventilation can profoundly affect the residents' well-being including health, motivation, morale, physical and mental well-being and satisfaction. ${ }^{15}$

So some familiar architectural works are considered to be biophilic design even though they were not technically designed due to the biophilic concerns. ${ }^{16}$ For instance; the "Fallingwater House" by Frank Lloyd Wright fulfils some of the direct, indirect and space/place experiences. Thus the

\footnotetext{
${ }^{11}$ Kellert \& Calabrese, $1980 . \quad{ }^{15}$ Browning et al., 2014.

${ }^{12}$ Kellert et al., 2008; Kellert, 2005; ${ }^{16}$ Moltrop, 2012.

Kellert and Finnegan, 2011; Brown- ${ }^{17}$ http://www.archdaily.com/tag/falling et al., 2014.

${ }^{13}$ Almusaed et al., 2006.
}

${ }^{14}$ Grinde and Grindal-Patil, 2009. 


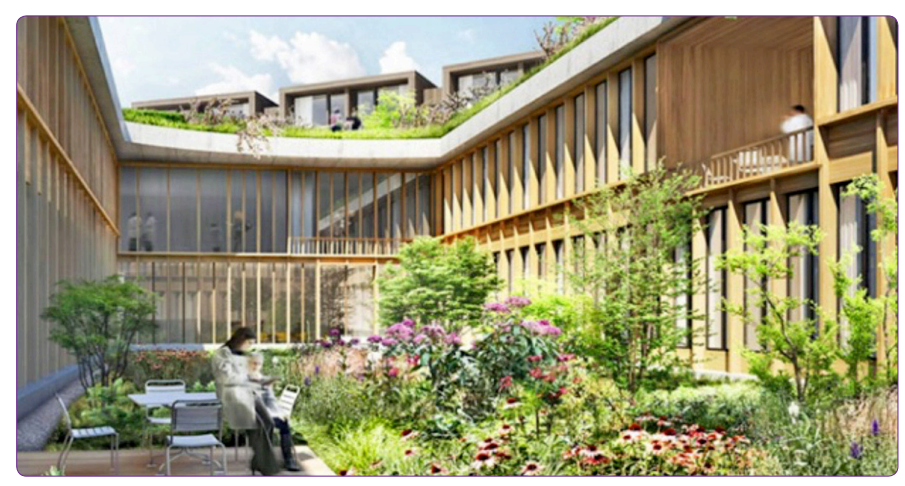

Figure 2. New North Zealand Hospital- Copenhagen, Herzog \& de Meuron \& Vilhelm Lauritzen Architects. ${ }^{19}$

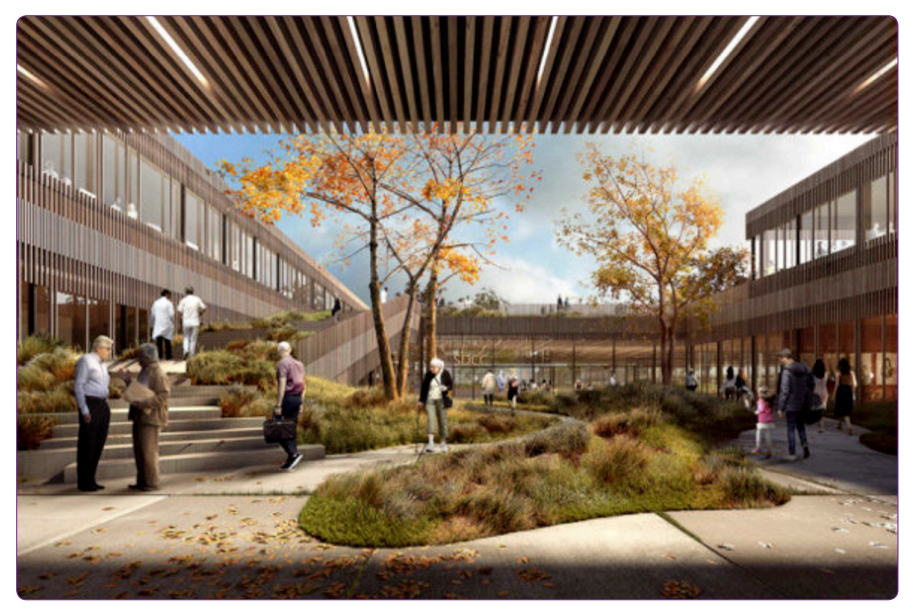

Figure 3. Steno Diabetes Center Copenhagen, Vilhelm Lauritzen Architects / Mikkelsen Architects. ${ }^{21}$

built environment does not necessarily need to interfere with biological human needs to commune neither with nature nor with the existing ecological systems.

A current example of the direct experience of nature and a strongly designed natural/built environment integration is the hospital design by Herzog \& de Meuron and Vilhelm Lauritzen in Denmark (project year 2014). The hospital organically reaches out into the wide landscape. Simultaneously its soft, flowing form binds many components of the hospital. It is a less-storeyed building that fosters exchange between staff and patients with a certain human scale despite its very large size. ${ }^{18}$

Another example, Steno Diabetes Center Copenhagen (project by COWI A/S, Vilhelm Lauritzen Architects, Mikkelsen Architects, year 2016) is based on the idea of creating a connection with the nature. The center weaves the indoors and outdoors together in order to stimulate and nurture the patients and the visitors. ${ }^{20}$

\footnotetext{
${ }^{18}$ Herzog de Meuron, $2017 . \quad{ }^{21}$ http://www.arch2o.com/wp-

${ }^{19} \mathrm{http}: / /$ inhabitat.com/wp-content/ content/uploads/2017/01/ blogs.dir/1/files/2014/04/herzog- Arch2O-Steno-Diabetes-Centerde-meuron-North-Zealand-Hospi- Copenhagen-Vilhelm-Lauritzental-706x369.jpg

${ }^{20}$ Archdaily, 2017.
}

In summary, current examples show that even though the concept of biophilia can not be found in the explanatory reports, these projects are the successful examples of biophilic design with all these characteristics.

This study focuses on the relation of humans with the nature from the building design perspective. The extend of the design studio is explored in terms of young designers' awareness on the issue and making it a matter of design input. The question including multi-functional building is crucial because it opens a venue to consider the experiences and attributes of biophilic design that Kellert and Calabrese $^{22}$ have recently suggested (see Figure 4 and the explanations behind). So the space is re-considered to be complete, complex and sustainable as the design process continues. The tendencies of the students are assessed in this regard and their attitudes towards versatile design questions related to the main issue are studied. This study points out that biophilia refers to the natural elements adapted to the everyday living spaces. The adaptation necessity for people living the urban life and the criteria of biophilia are the essences of design strategies. So they should be regarded as the main inputs and taken into consideration by the young designers. The studio is a preliminary experience that explores the design tendencies towards such a basic issue.

\section{Patterns and Principles of Biophilic Design}

A gradual development regarding the biophilic design studies is observed in the literature. The studies beginning from the 1990s have been modified and re-considered and even simplified through the years. Kellert ${ }^{23}$ reflects an "innovative approach" to the design of built environment. He states the new paradigm restorative environmental design in order to avoid excessive energy, resources and materials consumption, large amounts of waste and pollutants generation, alienation from the nature. This green design approach claims some certain objectives such as organic design that bases on true sustainable design, organic design that refers to the shapes and forms which "directly, indirectly or symbolically" inherits the natural environment. Vernacular design is another objective that attaches culture, history and ecology in the geographic context.

Kellert provided a set of criteria for the biophilic design. In the early literature he mentioned six dimensions:

1. Environmental features,

2. Natural shapes and forms,

3. Natural patterns and processes,

4. Light and space,

5. Place-based relationships,

6. Evolved human-nature relationships

\footnotetext{
${ }^{22}$ Kellert and Calabrese, 2015. $\quad{ }^{23}$ Kellert, 2005.
} 


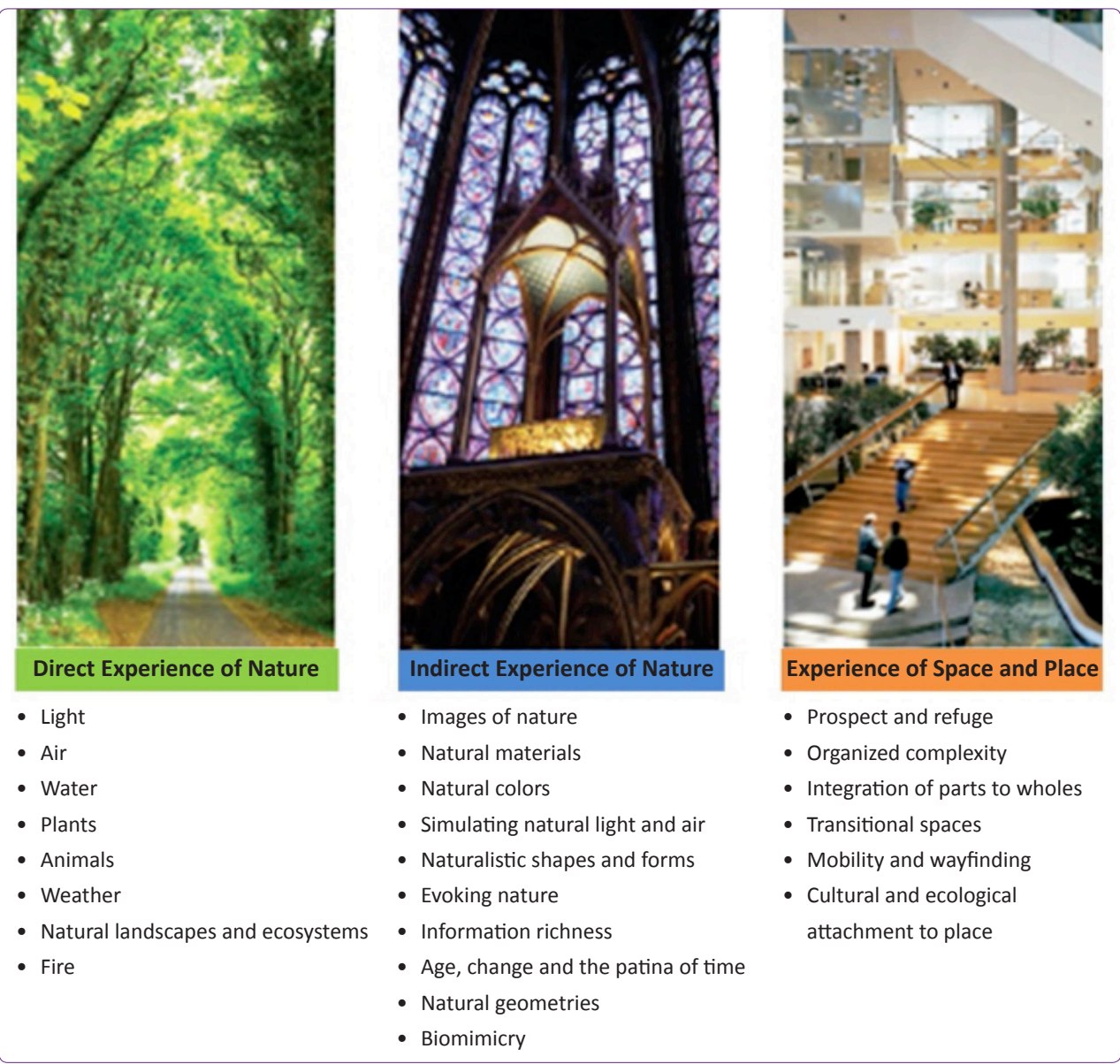

Figure 4. Experiences and attributes of biophilic design. ${ }^{26}$

of biophilic design encompassing seventy principles. ${ }^{24}$ In the recent study by Kellert and Calabrese ${ }^{25}$ these dimensions are simplified and formulated as a condensed list of criteria under the title "the experiences and attributes of biophilic design":

1. Direct experience of nature: Direct experience of nature is based on the building design that directly makes use of the natural elements such as light, air, water, plants, animals, weather, natural landscapes and ecosystems and fire. In terms of direct experience the architectural design formulates the building considering some of these components and they should be experienced by the users.

2. Indirect experience of nature: The indirect experience of the nature, and attribution to the natural elements are emphasized in the design. The images of nature, natural materials, natural colours, simulating natural light and air, naturalistic shapes and forms, evoking nature, information richness, age, change and the patina of time, natural geometries and biomimicry are the main methods.

3. Experience of space and place: The components of this criterion refer to the natural connections of space, sense of

\footnotetext{
${ }^{24}$ Kellert, 2008. ${ }^{25}$ Kellert and Calabrese, 2015. ${ }^{26}$ Kellert and Calabrese, 2015.
}

place and natural connotations. Prospect and refuge, organised complexity, integration of parts to wholes, transitional spaces, mobility and wayfinding and cultural and ecological attachment to the place make reference to the natural settings that the humans are accustomed to (Fig. 4).

Browning et al. ${ }^{27}$ refers to a different categorisation; "14 Patterns of Biophilic Design". They are also exercised as the criteria of architectural design combining the humans with the natural elements:

1. Nature in the space: Visual connection with the nature, non-visual connection with the nature, non-rhythmic sensory stimuli, thermal and airflow variability, presence of water, dynamic and diffuse light, connection with natural systems.

2. Natural analogues: Biomorphic forms and patterns, material connection with the nature, complexity and order.

3. Nature of the space: Prospect, refuge, mystery, and risk/peril.

Both well-known classifications which aim to transform biophilic design into a set of criteria, show a great deal of

\footnotetext{
${ }^{27}$ Browning et al., 2014
} 
similarity. The three main headings that they both describe are very close to each other in terms of meaning. The subheadings contain criteria that are largely the same, partly expressed in different words. Both classifications were examined within the scope of the study and was decided that Kellert's classification would be more appropriate to use since Kellert's classification could be a more comprehensive tool developed and refined over the years.

\section{Methodology}

In order to raise awareness for the biophilic approach on the architectural design, a studio scenario dealing with a mixed-use education function design was edited and applied to the third-year undergraduate architecture students. How students approach and reflect the biophilic tendencies to their designs was a curiosity for the studio tutors. The methodology is based on ethnographic research where the tutor is also the observer of the studio process. The end products are the assessment elements used in this study. End products and the continuum of the teaching process are also studied in other literature on design studio experience. For instance the study by Walliss and $\mathrm{Greig}^{28}$ refers to the reports and analyses of student attitudes and responses obtained from focus groups held during some particular time within the teaching process.

The research methodology approach is qualitative due to the nature of the architecture design. It should be noted that some teaching interventions are conducted as involuntary reflections by the tutors. Thus; the methodology suits the philosophy of interpretivism; which is one of the three main methods of qualitative research. This way of study refers to the philosophers Husserl and Heiddeger whose tradition is adapted to social sciences. The aim of interpretivism is to make meaning via complex nature of live experience with respect to the individual's perspective that lived it in person. It should be noted that the methodology bases on the first person's point of view and subjective experience. Literature refers to the Cartesian split between subject and object, mind and matter in this regard; thus the challenge is "to develop an objective interpretive science of subjective human experience $^{\prime 29}$ The paper reviews 46 student projects produced in the 2016-2017 fall semester due to the interpretivist qualitative research methodology. The final works are evaluated regarding Kellert's recent categorisation of biophilia (the main three criteria) and displayed in a systematic order (see Table 2). The authors sought the traces of the Kellert's criteria regarding components (sub-criteria mentioned under each title). Then a table is developed displaying the present and lacking elements. The speculations are derived regarding this table. The approach of

\footnotetext{
${ }^{28}$ Walliss and Greig, 2009. $\quad{ }^{29}$ Groat and Wang, 2002.
}

the young designers to the biophilia problem and their sensitivities on the issue are discussed. The reasons for such approaches are discussed considering the teaching methods in the studio, essences of architectural education and the previous literature.

The limitation of the study is the insufficiency to allocate wider time to the theoretical reading-discussion process on the biophilic design and architecture. In this way some sub-criteria that are not sufficiently understood can be analysed and included in the projects by the students.

Engaging the Biophilia Issue with the Studio Teaching

The practice of biophilic design involves the application of varying design strategies; named as experiences and attributes. The choice of design applications to "employ inevitably varies depending on a project's circumstances and constraints including particular building and landscape uses, project size, varying economic, logistical and regulatory factors, as well as cultural and ecological conditions" ${ }^{30}$ The design studio process considers the effective practice of biophilic design in addition to the requirements coherent to the building programme. The studio teaching also stresses the coherence between the natural setting and necessities of the user. This claim refers to both indoors and outdoors of the built environments; how they are interpenetrated and if the elements combining these two domains include biophilic attributes. From the designers' point of views "biophilic design patterns have the potential to reposition the environmental quality conversation to give the individual's needs equal consideration alongside with the conventional parameters for building performance that have historically excluded health and well-being" ${ }^{31}$ The studio seeks for "diverse applications mutually reinforce and complement one another, resulting in an overall integrated ecological whole". ${ }^{32}$

The studio teaching methodology combines three main variables: workshop, emphasis on site analysis and connection with the surroundings (See Table 1). The question of biophilia covers these variables and is embedded in every action such as discussions on the works, dialogues with the students and peer assessments that take place in the studio hours. The determination of the project scale is crucial since the varieties of attributes are considered accordingly. Building areas consisting of four to six plots (about 250 meter squares each) are addressed. The scale of the design is limited to $1500-3000$ meter squares. There were two levels of third year architecture students in the studio; the juniors (the students who take the courses of the fifth semester) and the seniors (the students who take the courses of the sixth semester). The building programme for the fifth semester students consists of education spac- 


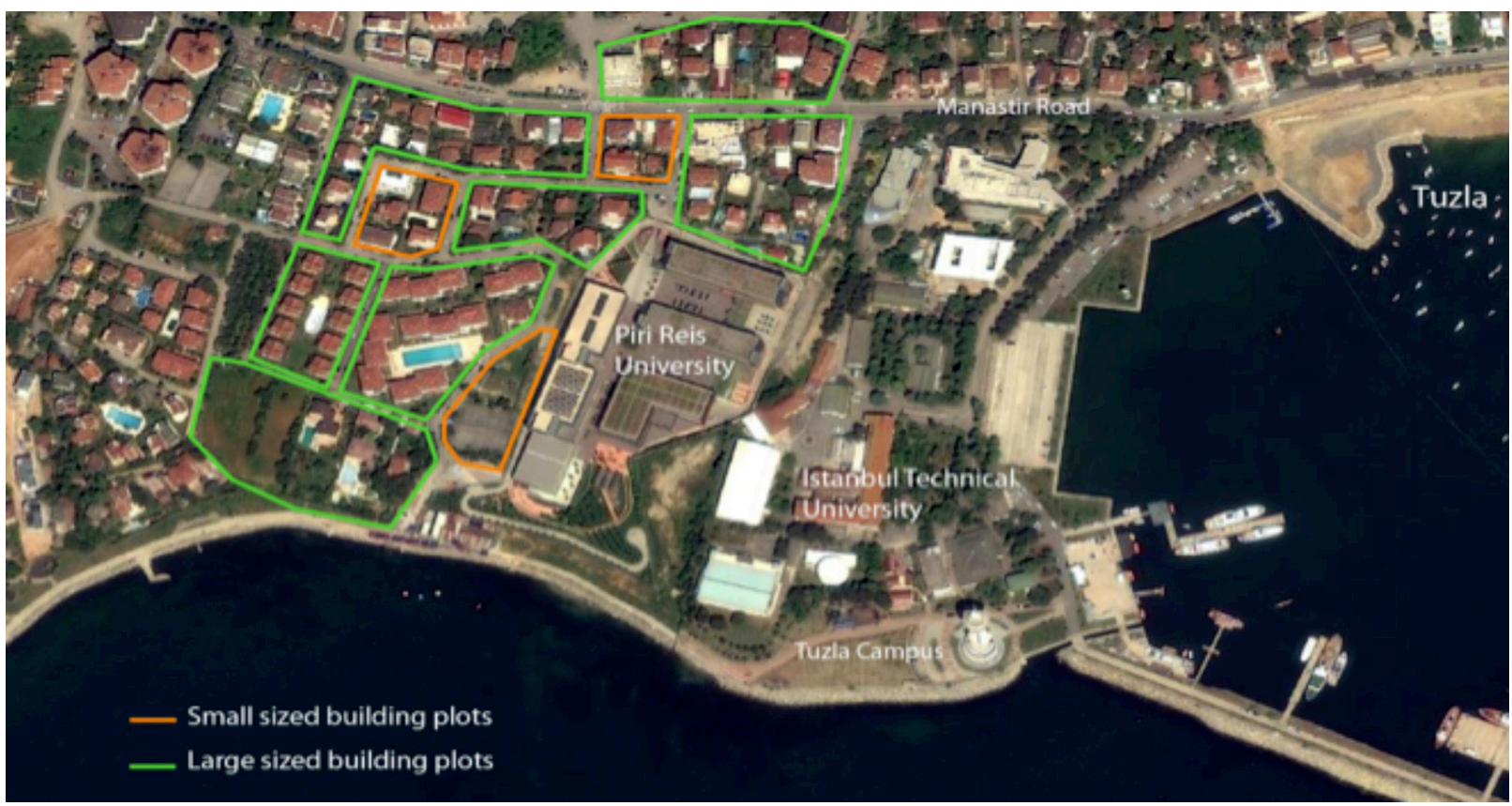

Figure 5. The project areas suggested and their scales with respect to the building programmes.

es, gathering areas, library, flexible office spaces, bookshop and cafeteria. The building programme for the sixth semester students includes accommodation in addition to other functions of the fifth semester group. The project areas are addressed according to the requirements of both programmes mentioned and sufficient building plot sizes (see Fig. 5).

The project area takes place on the Southern sub-urban coast of Istanbul, Tuzla; some more input is added to the biophilic design essences. The artefacts on the sea-fronts are re-considered. The relations between sea-fronts, roads and pedestrian passages are formulated accordingly. Opening the notion of education to the entire town and embedding it to the social life are emphasized. The functions of learning and studying are connected with taking breaks and leisure times activities (see Fig. 2). The provision of flexible design is imposed to students due to the essences of biophilia concept. The importance of working on silhouettes due to the in-situ characteristics (the sea fronts, topography and etc.) is stressed due to the experience of space and place attribute of the biophilic design. The studio process previsions that the setting, current buildings, urban elements and concepts in the project's area to be the parts of design. So creating a common language with the natural setting and merging/disconnecting functions/spaces/forms in this regard are studied in the design proposals.

The whole semester consisting of 14 weeks are divided into three parts in order to create a holistic approach towards the design problem. The first part is the experimental design under the name "a day of workshop". In this exercise each student is asked to work on one particular ecological element on the project area they selected for design by model-making. The main input in the studio is the critical discussion of the work on biophilia. The critical approach is not only the concluding assessment of the design studio process; but also a way to learn upon the design platform. Thus; the critical perspective is perceived as a "recurring challenge of architectural education" in order to integrate the main lecture format of the conventional courses into the learning by experience and by doing. ${ }^{33}$ After the workshop, a discussion on the workshop products took place concerning the application possibilities of biophilic attributes. In the second part the project areas are studied in terms of area analysis. Speculations on the project areas' potential formulations are studied. Cons and pros of the areas are discussed via mappings. The objectives of design teaching evolve regarding the creative approach of that design intensity. Goldschmidt ${ }^{34}$ explains this tendency by referring to "creativity" which is not a notion to teach, but to identify and encourage. The predictions are made regarding the characteristics of the project areas. In the third design studio part, the design interventions are implicated on the micro scale. So the details of the projects are studied with respect to the holistic approach to the question (see Table 1). Oxman ${ }^{35}$ states that relational thinking embraces the possibility of the critical thinking improvement. Within an intellectual atmosphere created in the design studio to be the core, biophilia is studied on the design exercises.

\footnotetext{
${ }^{33}$ Gross \& Do, 1997.
} 
Table 1. The outline of the teaching plan of the $3^{\text {th }}$ grade $\left(5^{\text {th }} \& 6^{\text {th }}\right.$ semester) studio

\begin{tabular}{|c|c|c|}
\hline Week & Studio teaching methodology & Outputs (results) and observations \\
\hline \multirow[t]{2}{*}{1} & Introduction to the studio Programme & Site analysis \\
\hline & Lectures on Biophilia notion Site visit & Work scale: $1 / 1000$ \\
\hline \multirow[t]{3}{*}{2} & Experimental design "A day of workshop" & Application of biophilic elements to the in-situ on site models \\
\hline & & Dialogue with the students on the application methods of biophilia \\
\hline & & Work scale: $1 / 500$ \\
\hline \multirow[t]{3}{*}{ 3-5 } & Focus on the Project area & Space-function formulations \\
\hline & Integration of biophilia with the design question & Holistic approach to the site \\
\hline & & Work scale: $1 / 500$ \\
\hline \multirow[t]{4}{*}{$6-9$} & Architectural interventions & Micro scale design proposals \\
\hline & & Specific function relations \\
\hline & & Congruity with biophilia and urban setting \\
\hline & & Work scale: $1 / 200$ \\
\hline \multirow[t]{2}{*}{$10-14$} & Final Project & The final design proposal that include the previous four steps above \\
\hline & & Work scale: $1 / 100$ \\
\hline
\end{tabular}

\section{Results and Discussion}

The end-products are evaluated and the table is developed displaying the present and lacking elements of the projects regarding Kellert's categorisation of biophilic design. (see Table 2) An evaluation team of three studio tutors assessed each student's design outcomes based on the biophilic design criteria. This team also observed the 14-week design development process of the students as studio tutors. The information on the table has been obtained on the basis of the midterm juries and weekly revision notes carried out within a period of 14 weeks besides of the end-products.

In this study, 45 out of 46 students of the design studio (except 1 student) were found to have met with the subject of "biophilic design" at the first studio course of the semester. After the presentations, workshops and discussions realized within the program, a "biophilic design conception" was formed in the mind of each student. The main aim of the work is to show how architectural students reflect on this concept and what principles they incorporate into their design. In this context, as a result of evaluating 46 projects using Kellert's triple classification, the following findings were obtained;

\section{- Direct Experience of Nature}

Both the observations made during the 14-week semester and inferences via Table 1 put forward that the students' most identified subjects with biophilic design are those under the category of "direct experience of nature". The principles that could exist at high levels in projects such as "light", "air", "plants" were able to take place at high level because of their ease of being included in designs by perceptible methods. It has been noticed that the integration with the green texture, topography and natural landscape is understood more than direct experience of nature from the majority of students use green roofs in their projects, protect the natural landscape by placing the design under the ground, or gently infiltrate the structure into the existing natural landscape. It can be assumed that direct experience of nature is also an issue in conventional design tendencies. So a specific knowledge for such elements in the design is not necessary. Moreover such elements are the most well-known features of nature that almost everyone experiences such as waves as a reference to form; or the wind that redirects the placement of the buildings (see Figure 3 ). They are the tangible elements as the surrounding input. Moreover direct experiences of nature are simple tools to create design elements.

However, it is estimated that the principles such as "fire" and "animals" have little or no involvement. It suggests that these principles refer to interior design discipline rather than architectural design discipline. The low presence of the "water" principle probably arises from the fact that the project area is located near the seaside and to establish a visual relationship with the sea preferred instead of any artificial water element. Nevertheless the integration of plants, natural landscape and ecosystems seem to be rather lower. According to the evaluation criterias, the usage of plants does not necessarily establish the connection between the natural landscapes and the ecosystems in every case.

\section{- Indirect Experience of Nature}

The objective of the indirect experience of nature is to provide symbolic/representational design elements within the built environment that allow users to make connections with the nature. The category of "the indirect experience of nature" could unfortunately involve a very low rate 
Table 2. Assessment of the end-products in the architectural design studio

\begin{tabular}{|c|c|c|c|c|c|c|c|c|c|c|c|c|c|c|c|c|c|c|c|c|c|c|c|c|}
\hline \multirow[b]{2}{*}{$\begin{array}{l}\text { The } \\
\text { Application } \\
\text { of Biophilic } \\
\text { Design in the } \\
\text { Architectura } \\
\text { Design } \\
\text { Studio }\end{array}$} & \multicolumn{8}{|c|}{ Direct Experience of Nature } & \multicolumn{10}{|c|}{ Indirect Experience of Nature } & \multicolumn{6}{|c|}{ Experience of Space and Place } \\
\hline & 壱 & 京 & 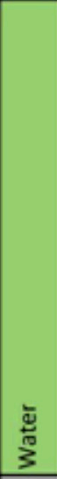 & $\begin{array}{l}\frac{n}{\tilde{E}} \\
\frac{\pi}{a}\end{array}$ & $\begin{array}{l}\frac{n}{\pi} \\
\frac{\mathrm{E}}{5} \\
\frac{E}{4}\end{array}$ & 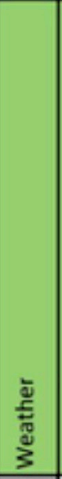 & 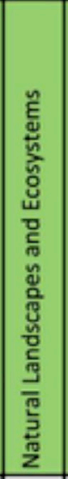 & 는 & 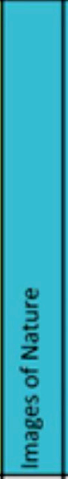 & 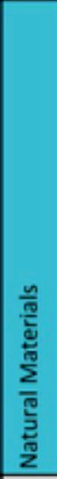 & $\begin{array}{l}\frac{n}{\circ} \\
\frac{3}{3} \\
\frac{\pi}{3} \\
\frac{\pi}{2} \\
\end{array}$ & 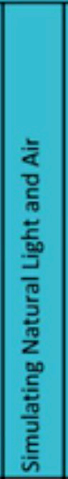 & 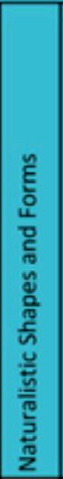 & 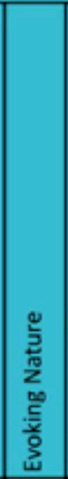 & 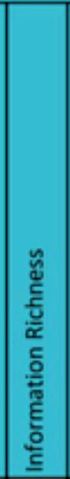 & 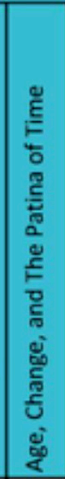 & 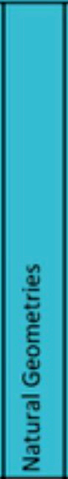 & $\begin{array}{l}\frac{\text { L }}{\mathrm{E}} \\
\frac{\mathrm{E}}{\mathrm{E}} \\
\frac{\mathrm{o}}{\mathrm{\omega}}\end{array}$ & 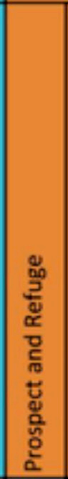 & 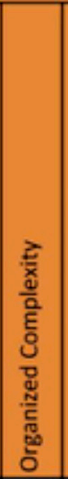 & 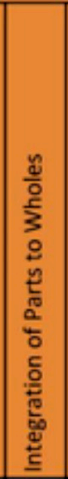 & 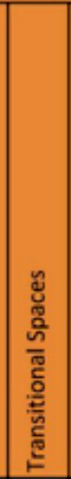 & 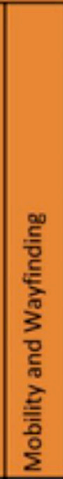 & 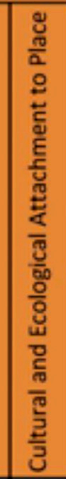 \\
\hline \begin{tabular}{|l|} 
Student 1 \\
\end{tabular} & 0 & O & 0 & O & & 0 & & & & & & & & & & & & & & 9 & ? & 0 & ? & O \\
\hline Student 2 & O & O & O & ? & & O & & & & 0 & O & & & & & & & & O & & O & 0 & 0 & \\
\hline Student 3 & ? & 0 & & - & & & ? & & & & & & & ? & 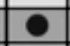 & & P & ? & ? & & O & 운 & ? & O \\
\hline Student 4 & O & 0 & & 0 & & & & & & & & & & & & & & & O & & & 0 & O & \\
\hline Student 5 & ? & & O & 인 & O & ? & O & & & & & & ? & 0 & ? & & O & ? & 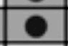 & O & O & & 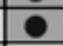 & \\
\hline Student 6 & ? & & ? & 0 & & & & & & & & & & & & & & & & & ? & & 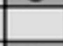 & \\
\hline \begin{tabular}{|l|} 
Student 7 \\
\end{tabular} & 0 & 0 & & & & O & & & & & & & & & & & & & O & & & & 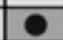 & \\
\hline $\begin{array}{l}\text { Student } 8 \\
\end{array}$ & 0 & 0 & & 0 & & & & & & & & & & & & & & & 0 & & & & 0 & \\
\hline \begin{tabular}{|l|} 
Student 9 \\
\end{tabular} & ? & 0 & & ? & & & 0 & & & 0 & O & & & & & & & & O & O & 0 & & 0 & 0 \\
\hline \begin{tabular}{|l} 
Student 10 \\
\end{tabular} & 0 & 0 & & 0 & 0 & & & & & & & & & & & & & & 0 & & 0 & & 0 & \\
\hline Student 11 & ○ & 0 & & 0 & O & 0 & & & & 0 & 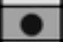 & & & & - & & & & 1 & & & - & 0 & 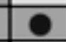 \\
\hline \begin{tabular}{|l} 
Student 12 \\
\end{tabular} & ? & 0 & & 0 & & & & & & & & & & & & & & & 0 & & & & 0 & \\
\hline Student 13 & 0 & 0 & & 0 & & & 0 & & & & & & 0 & 0 & & & & & 1 & & O & & 0 & \\
\hline \begin{tabular}{|l|} 
Student 14 \\
\end{tabular} & 0 & 0 & & 0 & & 0 & & & & & & & & & & & & & 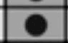 & & 0 & 0 & 0 & \\
\hline \begin{tabular}{|l} 
Student 15 \\
\end{tabular} & 0 & 0 & & & & & & & & & & & 0 & 0 & & & O & & 0 & & O & & & \\
\hline \begin{tabular}{|l} 
Student 16 \\
\end{tabular} & 인 & 0 & & 인 & & 0 & & & & & & & & & & & & & 0 & & C & & 0 & \\
\hline \begin{tabular}{|l} 
Student 17 \\
\end{tabular} & 0 & 0 & & 0 & & & & & & & & & & & & & & & 0 & & 0 & & 0 & \\
\hline $\begin{array}{l}\text { Student } 18 \\
\end{array}$ & 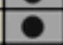 & 0 & O & 9 & & 0 & 0 & & & & & & & & & & & & 0 & & 9 & & 0 & O \\
\hline \begin{tabular}{|l|} 
Student 19 \\
\end{tabular} & 0 & 0 & & 인 & & & 0 & & & & & & 0 & & & & & & 0 & & 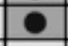 & & 0 & ? \\
\hline Student 20 & 0 & 0 & O & ? & & & & & & & & & & & & & & & 0 & & & & & \\
\hline \begin{tabular}{|l} 
Student 21 \\
\end{tabular} & 0 & 0 & & 0 & & & 0 & & & & & & 0 & 0 & & & 0 & & 0 & & 0 & 0 & & 0 \\
\hline \begin{tabular}{|l} 
Student 22 \\
\end{tabular} & 0 & 0 & & & & & 0 & & & & & & & & & & & & 0 & & & & 0 & \\
\hline \begin{tabular}{|l} 
Student 23 \\
\end{tabular} & 0 & 9 & & ? & & O & & & & & & & & & & & & & 0 & & 0 & ? & 0 & \\
\hline Student 24 & 인 & 0 & & 인 & & 당 & & & & & & & & & & & & & 웅 & & & 인 & 잉 & \\
\hline \begin{tabular}{|l} 
Student 25 \\
\end{tabular} & ? & 0 & & - & & & 0 & & & & & & 0 & 0 & & & O & & 인 & & 인 & & 인 & 0 \\
\hline Student 26 & O & 0 & 0 & 9 & & & & & & & & & & & & & & & 0 & & 0 & & 0 & O \\
\hline \begin{tabular}{|l} 
Student 27 \\
\end{tabular} & 0 & 0 & & 0 & 0 & & & & & 0 & 0 & & & & & & & & 0 & & 0 & & 0 & \\
\hline Student 28 & 0 & 0 & & 0 & & 0 & 0 & & & & & & 0 & 0 & 0 & & O & 0 & 0 & O & 0 & 0 & 0 & O \\
\hline \begin{tabular}{|l} 
Student 29 \\
\end{tabular} & 잉 & ? & & 0 & ? & & & & & & & & 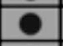 & & & & & & 인 & & & & 인 & \\
\hline \begin{tabular}{|l} 
Student 30 \\
\end{tabular} & 0 & 0 & 0 & 잉 & 0 & 0 & 0 & & & 0 & O & & 0 & 0 & & & 0 & 0 & O & 0 & 0 & & 0 & 0 \\
\hline Student 31 & 0 & 0 & & 0 & 0 & 0 & & & & & & & & & & & & & 0 & & & & 0 & \\
\hline Student 32 & ○ & 0 & & 0 & & & & & & & & & & & & & & & 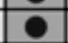 & & O & O & 0 & \\
\hline \begin{tabular}{|l} 
Student 33 \\
\end{tabular} & 0 & 0 & & 0 & 0 & 0 & & & & & & & & & & & & & 0 & & 0 & & 0 & \\
\hline $\begin{array}{l}\text { Student } 34 \\
\end{array}$ & 인 & 0 & & 0 & & 0 & & & & & & & & & & & & & 인 & & & ? & 0 & ? \\
\hline \begin{tabular}{|l|} 
Student 35 \\
\end{tabular} & 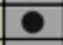 & 0 & & & & & & & & & & & & & & & & & 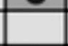 & & 0 & 0 & & \\
\hline \begin{tabular}{|l} 
Student 36 \\
\end{tabular} & 0 & 0 & 0 & 0 & & 0 & 0 & & & 0 & 0 & & & & & & & & 0 & & ? & 0 & 0 & 0 \\
\hline \begin{tabular}{|l|} 
Student 37 \\
\end{tabular} & 0 & 0 & & 0 & & & & & & & & & & & & & & & 인 & & 0 & & 0 & \\
\hline Student 38 & 인 & 0 & & & & 인 & & & & & & & & & & & & & 인 & & & & 은 & 0 \\
\hline Student 39 & 0 & 0 & & 0 & & 0 & O & & & 0 & O & & 0 & 0 & & & O & & 0 & & 0 & 0 & 0 & 0 \\
\hline Student 40 & ○ & 9 & & & & 0 & 9 & & & 0 & C & & & & & & & & - & & 0 & & 0 & 0 \\
\hline Student 41 & 0 & 0 & & 0 & & 0 & & & & & & & & 0 & & & & & 0 & 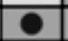 & 0 & & 0 & 0 \\
\hline \begin{tabular}{|l} 
Student 42 \\
\end{tabular} & 0 & 0 & & 9 & & 9 & ? & & & & & & 0 & 9 & & & 0 & & 0 & & 0 & 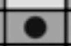 & 0 & 0 \\
\hline $\begin{array}{l}\text { Student } 43 \\
\end{array}$ & 0 & 0 & & 0 & 0 & 0 & 0 & & & 0 & O & & & & & & & & 0 & & 0 & 0 & 0 & 0 \\
\hline \begin{tabular}{|l} 
Student 44 \\
\end{tabular} & 잉 & 0 & & 인 & & & & & & & & & O & 0 & & & O & 0 & 잉 & & O & & 잉 & \\
\hline Student 45 & 인 & 0 & & & & & & & & & & & & & & & & & 0 & & & & 0 & \\
\hline \begin{tabular}{|l} 
Student 46 \\
\end{tabular} & 0 & \begin{tabular}{|l|}
0 \\
\end{tabular} & & 0 & 0 & & & & & & & & & & & & & & 0 & & 0 & & 0 & 0 \\
\hline \multirow[b]{2}{*}{ Results } & $46 / 46$ & \begin{tabular}{|l|l|}
$44 / 46$ \\
\end{tabular} & $9 / 46$ & $39 / 46$ & $10 / 46$ & $22 / 46$ & $16 / 46$ & $0 / 46$ & $0 / 46$ & $9 / 46$ & $9 / 46$ & $0 / 46$ & $12 / 46$ & $12 / 46$ & $4 / 46$ & $0 / 46$ & $10 / 46$ & $5 / 46$ & $43 / 46$ & \begin{tabular}{|l|}
$6 / 46$ \\
\end{tabular} & $33 / 46$ & $17 / 46$ & $41 / 46$ & $20 / 46$ \\
\hline & \begin{tabular}{|l|}
$100 \%$ \\
\end{tabular} & \begin{tabular}{|l|l|}
$96 \%$ \\
\end{tabular} & $20 \%$ & $85 \%$ & $22 \%$ & $48 \%$ & $35 \%$ & \begin{tabular}{|l|}
$0 \%$ \\
\end{tabular} & ox & $20 \%$ & $20 \%$ & \begin{tabular}{|l|} 
ox \\
\end{tabular} & \begin{tabular}{|l|}
$26 \%$ \\
\end{tabular} & $26 \%$ & \begin{tabular}{|l|}
$9 \%$ \\
\end{tabular} & $0 \%$ & 228 & $11 \%$ & \begin{tabular}{|l|}
$94 \%$ \\
\end{tabular} & \begin{tabular}{|l|}
$13 \%$ \\
\end{tabular} & 728 & $37 \%$ & $89 \%$ & $44 \%$ \\
\hline
\end{tabular}




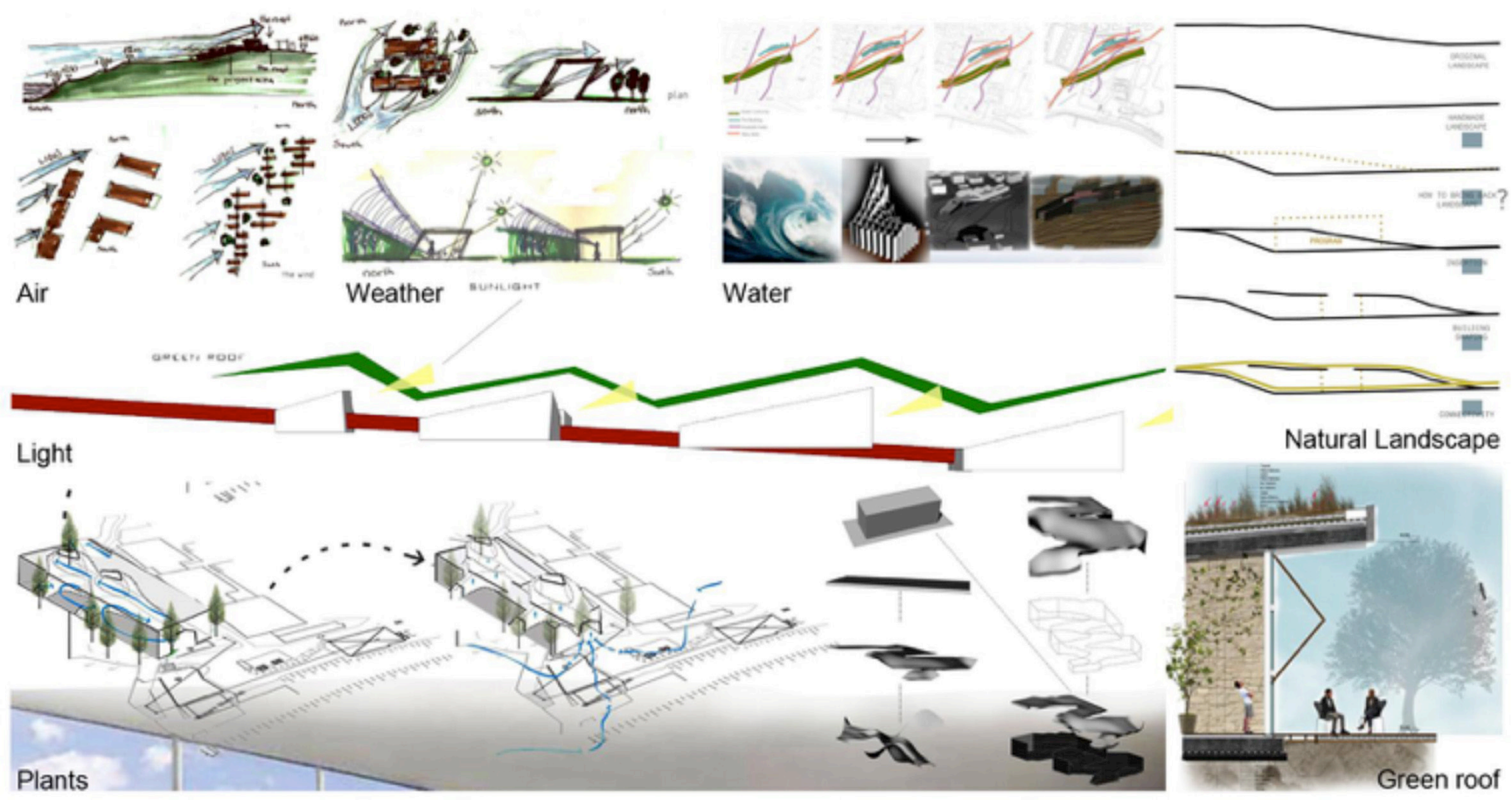

Figure 6. Direct experience of nature from student's design outcomes.

of 46 projects produced in the studio. While "natural materials", "natural colors", "naturalistic shapes and forms", "natural geometries" and "evoking nature" principles are located in a rather smaller rate, "images of nature", "stimulating natural light and air", "age, change and the patina of time" principles are not included in designs at all. The reasons for such exclusion is estimated that students perceive these principles as criteria to be considered in the interior design frame rather than architectural design. Moreover the heavy macro-scale design load of the studio does not leave enough time for interior space design in the period of 14 weeks of the studio and a relatively urban scale perspective (see Figure 4).

The principle of "information richness" needs to be studied on the complexity related to diversity and variation in the nature. All kinds of design decisions make a sensation and act upon the imagination and exploration of the user are included in the scope of information richness. A majority of students respond positively to the richness of the cognitive information, the diversity, relevant textures and details of the buildings and open spaces. Nevertheless, several traces of "information richness" have been observed at a lower percentage. It is evident that the students have applied particular elements in terms of indirect experience of nature. These interventions are mostly in the micro scales. The applications of biophilic tendencies to the designs are rather poor. The macro-scale biophilic design concepts have not been detected at a high rate. So indirect biophilic elements have not been integrated to the entire project; but formulated at particular partitions; such as green roof, skylight windows or usage of natural materials (See Figure 4, Information Richness Title) On the other hand, biomimicry is definitely closely related to biophilic design. However, biomimicry is a comprehensive study area not enough to be a subheading in the biophilic design. So it was not possible to handle it in the way it deserves in a limited studio case as the subject matter.

\section{- Experience of Space and Place}

The principles under the title of "experience of space and place" are already inherent in the architecture discipline beyond the biophilic design and intuitively taken into account by almost every designer. Probably for this reason, concepts like "prospect and refuge", "integration of parts to wholes" or "mobility and wayfinding" have become the principles that have been found in almost all the projects. However such criteria also tackles the design coherences with the natural setting as well as the built environment. So connections between the sea-fronts and the town are studied almost in all compatible design proposals (mobility and wayfinding). Walking paths, natural connection possibilities and continuity of the natural elements are placed in the designs in this manner. The designs are considered to be the parts of a whole in terms of integration (see Figure 5).

According to Herzog \& Bryce; "distant prospect (>100 feet, $>30$ meters) is preferred over shorter focal lengths (>20 feet, >6 meters) because it provides a greater sense 


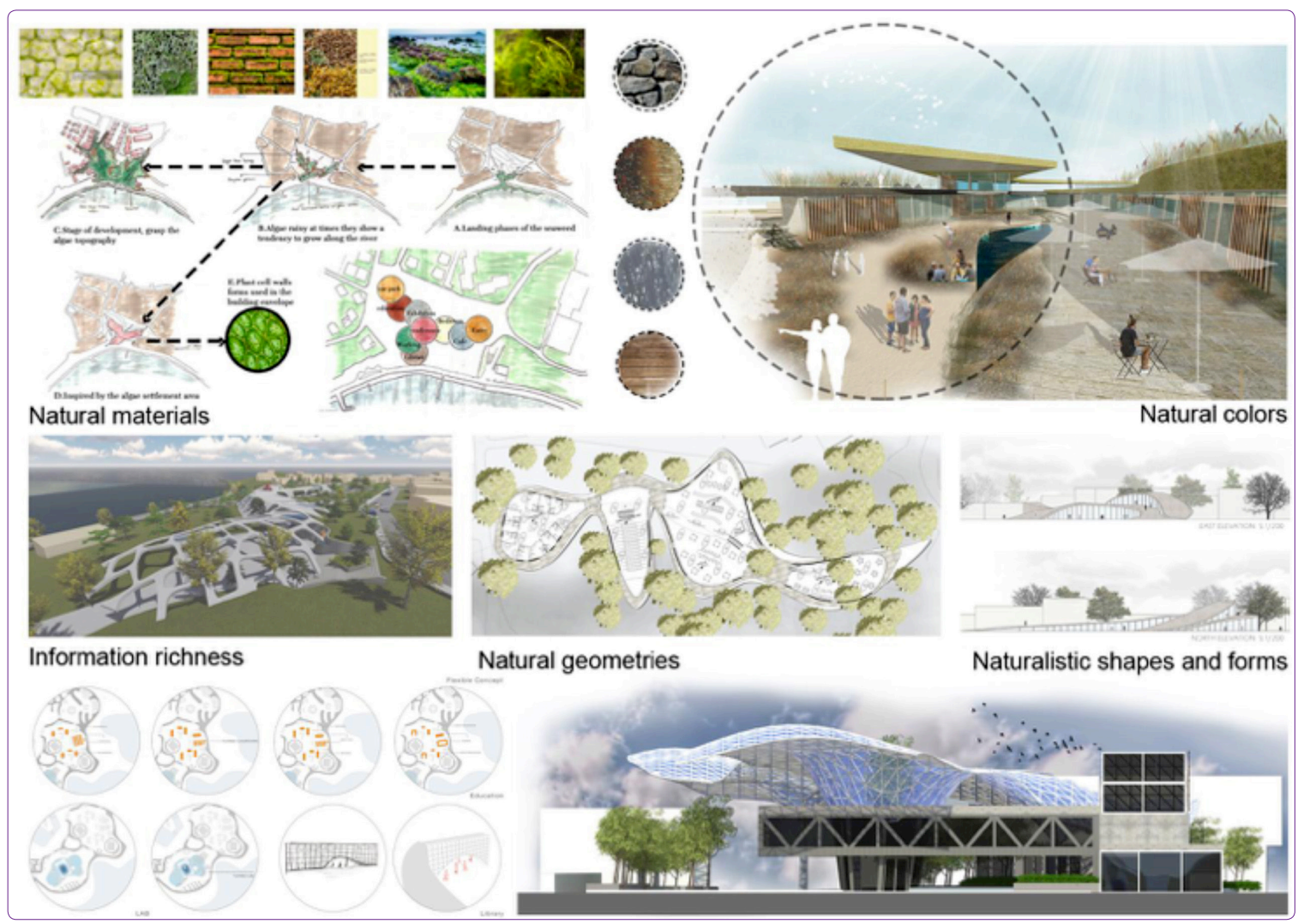

Figure 7. Indirect experience of nature from student's design outcomes.

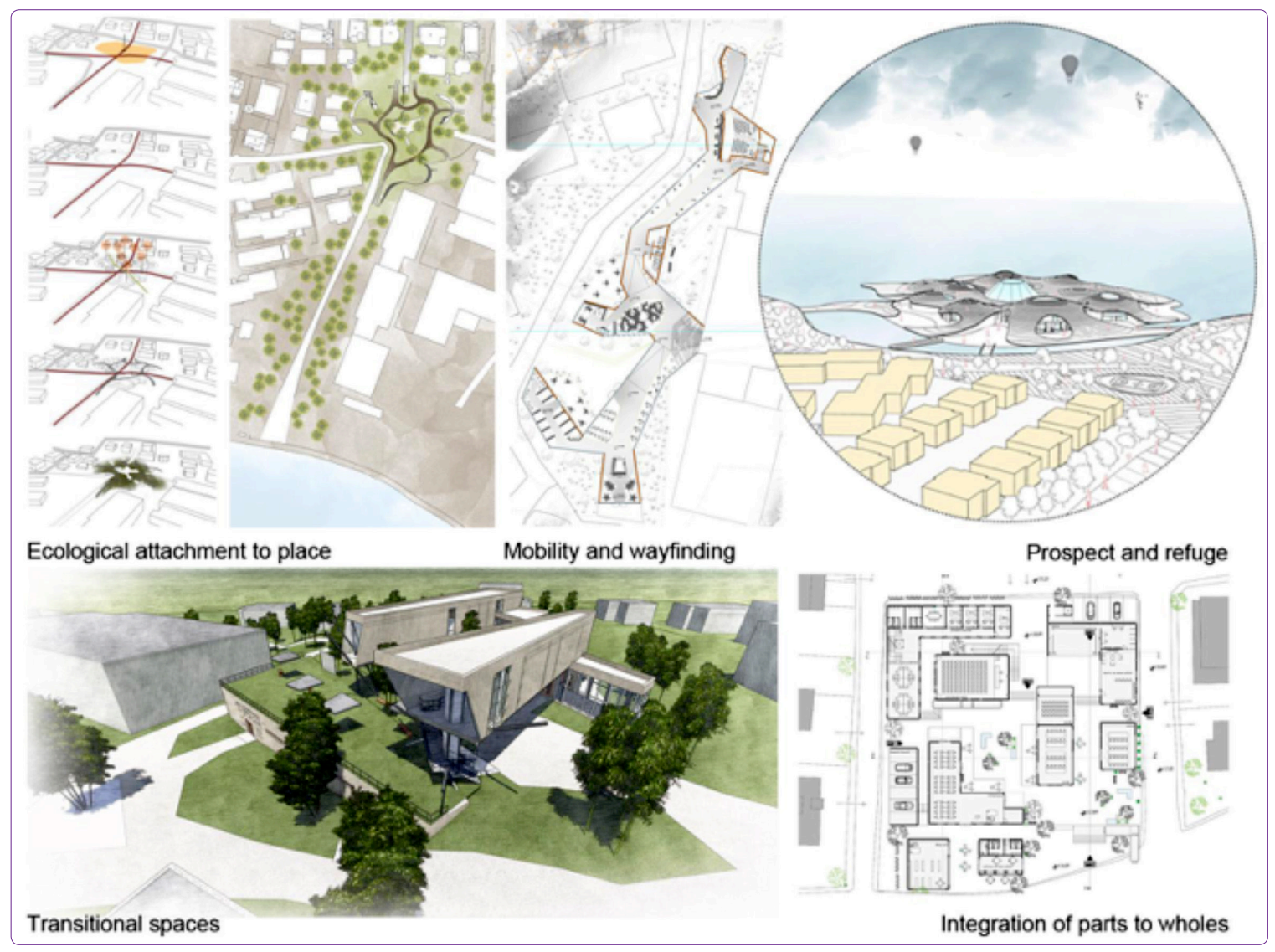

Figure 8. Experience of space and place. 
of awareness and comfort. ${ }^{36}$ Because of the position of the project area facing the sea from above, the ideal prospect distance has been achieved in most projects. However, naturally students motivated themselves to use "transitional spaces" in project designs related to environment and climate. Some of them strengthened the relationship with the environment, so they made cultural and ecological attachment to place. As mentioned in the "indirect experience of nature", criteria such as "organized complexity", "age, change and the patina of time" has been avoided because they are rather perceived as abstract.

When 46 design proposals produced in the studio are evaluated regarding the biophilic design principles, it is noted that the "direct experience of nature" and the "experience of space and place" patterns that are highly available in the projects. As known, principles such as light, air, plants, weather (direct principals in the scope of the biophilic design) and prospect/refuge, integration of parts to the whole, mobility and wayfinding, cultural and ecological attachment to the place (experience of space and place in the scope of the biophilic design) are adopted by students from the very beginning of architectural education. It should be noted that such natural input are also the main design elements in the conventional architectural design applications. However, it is found that the principles of the "indirect experience of nature" pattern are available at a lower rate in general design processes. Thus, the result displays that students can identify principles of "direct experience of nature" with biophilic design more than others. It is considered natural that the pattern "experience of space and place" should be highly observed in the projects because that particular title contains the principles which are closely related with the architectural design education.

It is observed that a few principals of Kellert's classification used in the evaluation of the projects were perceived as highly abstract by the students and such principles were taken into consideration at a lower rate. It is not correct to expect such a classification which is intended to provide a general framework, serve as a comprehensive design checklist. It is necessary to make extensive readings on each of the sub-criteria that students could not understand sufficiently. However, it cannot be said that theoretical researches were made thoroughly by the entire 46 students. Some students have included a few criteria into their projects without questioning the meaning in terms of the biophilic approach.

The consideration of "indirect experience of nature" at a low rate at projects is worth noting as almost all of the principles in this context are principles that can be included in the stage of interior design. The reason for this is the

\footnotetext{
${ }^{36}$ Herzog \& Bryce, 2007.
}

lack of time available for students in terms of interior design, due to the limited duration of the studio. Within the 14 weeks of semester time, the emphasis can only be given to major concepts and conceptual design process. The principles of each of the three main patterns are not also reflected in the projects in a homogeneous and balanced manner. It should be noted that the three main headings and the sub criteria of each are not equivalent in terms of the positive impacts on human beings.

\section{Conclusion}

As a general evaluation of the studio which identifies the biophilic design as the main design problem, achieved the following results;

It is important to allocate more time in order to be discussed and reflected each criterion of the biophilic design approach in the projects. There have been some limitations that have been put forward by the experiment on a relatively large scale, $3^{\text {th }}$ grade project. Since the duration of the studio period in the architecture schools is fixed, restricting the project area and scale will be the only solution. It is thought that it will be useful to retry in the future with a smaller scale-second year project with different variables (different function, land, context, etc.) and emphasize interior space design further.

There are cases where the tutors remain dilemma in the process of determining existence/absence of Kellert's criteria in the projects. It would be healthier to ask the students to evaluate their project in this context in order to be able to achieve this dilemma.

\section{Acknowledgements}

This study is based on the student works carried out in the $3^{\text {rd }}$ grade design studio of GTU Architecture department in the fall semester of 2016-2017. The authors wish to express their appreciation to directors (Özlem Aydın, Tarhan Arıkan, Nurşah Serter and Ayşegül Engin) and 46 students for their contributions in carrying out the research.

\section{References}

Almusaed, A., Almusaed, A., Abdushaik, Z. K. and Khalil, S. (2006). Biophilic architecture, the concept of healthy sustainable architecture. PLEA2006 - The 23rd Conference on Passive and Low Energy Architecture, Geneva, Switzerland.

Archdaily, (2017). "This Copenhagen Diabetes Center Connects Patients to Nature". http://www.archdaily.com/803283/thiscopenhagen-diabetes-center-connects-patients-to-nature [Date accessed 10.02.2017]

Browning, W.D., Ryan, C., Clancy, J. (2014), 14 Patterns of Biophilic Design, Improving Health \& Well-Being in the Built Environment. New York: Terrapin Bright Green.

Fromm, E. O. (1964). The Heart of Man. UK: Harpercollins.

Goldschmidt G., (2003), Expert knowledge or creative spark? Predicaments in design education, Expertise in Design, De- 
sign Thinking Research Symposium 6, Proceeding, 17-18 December, Sydney.

Grinde, B. and Grindal-Patil, G. G. (2009). Biophilia: Does Visual Contact with Nature Impact on Health and Well-Being?. International Journal of Environmental Research and Public Health, Int. J. Environ. Res. Public Health 6.

Groat \& Wang, (2002), Architectural Research Methods. New York: John Wiley and Sons.

Gross M. D. \& Do E. Y., (1997), The design studio approach: learning design in architecture education, Design Education Workshop (eds. J. Kolodner \& M. Guzdial), EduTech/NSF, College of Computing, Georgia Institute of Technology, September 8-9, Atlanta.

Heerwagen, J. H. and Hase, B. (2001). Building biophilia: connecting people to nature in building design. Environmental Design + Construction, Mar/Apr, 30-36.

Herzog de Meuron official website, (2017). New North Zealand Hospital; https://www.herzogdemeuron.com/index/projects/complete-works/401-425/416-new-north-zealand-hospital.html [Date accessed 10.03.2017]

Herzog, T. R. \& Bryce, A. G., (2007), Mystery and Preference in Within-Forest Settings, Environment and Behaviour, 39(6), 779-796.

Holm, Ivar (2006). Ideas and Beliefs in Architecture and Industrial design: How attitudes, orientations, and underlying assumptions shape the built environment. Oslo School of Architecture and Design.

Kellert S. R. \& Calabrese, E. F. (2015). The Practice of Biophilic Design, p. 9, 10, 11; www.biophilic-design.com [Date accessed 10.02.2017]

Kellert S.R., (2005). Building For Life: Designing and Understanding The Human-Nature Connection. Island Press, p. 143, 150.

Kellert S.R., Heerwagen J.H., Mador M.L. (2008). “Biophilic Design: The Theory, Science and Practice of Bringing Buildings to Life", Hoboken, NJ: John Wiley \& Sons, p. vii, viii, 3, 13.
Kellert, S. and B. Finnegan. (2011). Biophilic Design: the Architecture of Life. A 60 minute video; http://www.bullfrogfilms. com [Date accessed 10.02.2017]

Kellert, S., Heerwagen, J. and Mador, M. (2008). Biophilic Design: the Theory, Science, and Practice of Bringing Buildings to Life. Hoboken, NJ: John Wiley.

Krcmarova, J. E. O. (2009). Wilson's Concept of Biophilia and the Environmental Movement in the USA, Internet Journal of Historical Geography and Environmental History, Volume 6, 5.

Le Corbusier, (1952). Le Corbusier Foundation Official Website. Unite D'habitation, Marseille, France; http://www.fondationlecorbusier.fr/corbuweb/morpheus.aspx?sysld=13\&IrisObj ectld=5234\&sysLanguage $=$ en-en $\&$ itemPos $=58$ \&itemCount $=$ $78 \&$ sysParentld=64\&sysParentName=home [Date accessed 12.03.2017]

Moltrop, 2011. Biophilic Design: A Review of Principle and Practice. Dartmouth Undergraduate Journal of Science, Spring Issue.

Oxman R., (1999), Educating the designerly thinker, Design Studies, 20: 105-122.

Oxman R., (1999), Think-maps: teaching design thinking in design education, Design Studies, 25(1): 63-91.

Ryan, M., Saunders, C., Rainsford, E. \& Thompson, E. (2014), Improving research methods teaching and learning in politics and international relations: a 'reality show' approach, Politics, 34 (1), 85-97.

Walliss J. \& Greig J., (2009), Graduate design education: the case for an accretive model, International Journal of Art \& Design Education, 28(3): 287-295.

Wilson, E. O. (1984). Biophilia. Cambridge: Harvard University Press. p. 1, 35.

Wilson, E. O. (1993). Biophilia and the Conservation Ethic. in: Kellert, S. and Wilson, E. O. (eds): The Biophilia Hypothesis, Washington DC: Shearwater Books, p. 31.

Wilson, E. O. (1994). Naturalist. Washington DC: Shearwater Books, p. 360. 